\title{
The analysis of the relationship between organizational values and commitment with regard to the knowledge management of Kermanshah's tax department staff
}

\author{
Mehdi Sadeghi \& Sara Yazdanfar
}

\begin{abstract}
The present research has been carried out under the title of "The analysis of the relationship between organizational values and commitment with regard to the knowledge management of Kermanshah's Tax Department staff". The study is descriptive from the viewpoint of its aim and method of data collection. The Statistical population of this study consists of chief administrative officers, middle-ranked officers and operating officers, a total number of whom reaches 396 individuals.195 individuals were chosen as statistical samples. The means of data collection is three types of questionnaire concerning organizational values, knowledge management, and organizational commitment. The results of data analysis prove that there is a meaningful correspondence between organizational values and knowledge management but not a meaningful relationship between organizational commitment and knowledge management. Likewise, there is a correlation between the variable that predicts organizational values and the variable of knowledge management, while there is no meaningful relationship between the variable of organizational commitment and that of knowledge management.
\end{abstract}

Keywords:

organizational values; organizational commitment; knowledge management. 


\title{
Análise de relação entre valores organizacionais e compromisso em relação à gestão do conhecimento do departamento tributário da Kermanshah
}

Resumo: A presente pesquisa foi feita sob o título "A Análise da Relação Entre Valores Organizacionais e Compromisso em relação à Gestão do Conhecimento do Departamento Tributário da Kermanshah". O estudo é descritivo do ponto de vista do seu objetivo e método de obtenção de dados. A população estatística deste estudo consiste nos chefes administrativos, nos administrativos de classificação intermédia e nos escriturários, num total de 396 indivíduos. 195 dos indivíduos foram escolhidos por amostra estatística. O meio de obtenção de dados foi três tipos de questionários relacionados com valores organizacionais, conhecimento de gestão e compromisso organizacional. Os resultados dos dados da análise provam que existe uma correspondência significativa entre valores organizacionais e gestão de conhecimento mas não uma correspondência significativa entre compromisso organizacional e gestão de conhecimento. Da mesma forma, há uma correlação entre a variável que prevê valores organizacionais e a variável de gestão de conhecimento, enquanto que não há uma relação significativa entre a variável de compromisso organizacional e gestão de conhecimento.

Palavras-chave: valores organizacionais; compromisso organizacional; gestão de conhecimento.

\section{L'analyse de la relation entre les valeurs organisationnelles et l'engagement en ce qui concerne la gestion des connaissances du personnel du département des impôts de Kermanshah}

\begin{abstract}
Résumé: La présente recherche a été réalisée sous le titre de «L'analyse de la relation entre les valeurs organisationnelles et l'engagement en ce qui concerne la gestion des connaissances du personnel du département fiscal de Kermanshah". L'étude est descriptive du point de vue de son objectif et de la méthode de collecte des données. La population statistique de cette étude est composée de directeurs généraux, de cadres moyens et d'agents d'exploitation, dont un total de 396 personnes. 195 individus ont été choisis comme échantillons statistiques. Les moyens de collecte de données sont trois types de questionnaire concernant les valeurs organisationnelles, la gestion des connaissances et l'engagement organisationnel. Les résultats de l'analyse des données prouvent qu'il existe une correspondance significative entre les valeurs organisationnelles et la gestion des connaissances, mais pas une relation significative entre l'engagement organisationnel et la gestion des connaissances. De même, il existe une corrélation entre la variable qui prédit les valeurs organisationnelles et la variable de gestion des connaissances, alors qu'il n'y a pas de relation significative entre la variable de l'engagement organisationnel et celle de la gestion des connaissances.
\end{abstract}

Mots-clés: valeurs organisationnelles; l'engagement organisationnel; gestion des connaissances.

\section{El análisis de la relación entre valores organizacionales y el compromiso con respecto a la gestión del conocimiento del personal del departamento de impuestos de Kermanshah}

\footnotetext{
Resumen: La presente investigación se ha llevado a cabo bajo el título de "análisis de la relación entre los valores organizacionales y el compromiso con respecto a la gestión del conocimiento del personal del Departamento de Impuestos de Kermanshah". El estudio es descriptivo desde el punto de vista de su objetivo y método de recopilación de datos. La población estadística de este estudio está compuesta por oficiales administrativos principales, oficiales de rango medio y oficiales de operaciones, un total de 396 individuos. 195 individuos fueron elegidos como muestras estadísticas. Los medios de recopilación de datos son tres tipos de cuestionarios sobre valores organizacionales, gestión del conocimiento y compromiso organizacional. Los resultados del análisis de datos demuestran que existe una correspondencia significativa entre los valores de la organización y la gestión del conocimiento, pero no una relación significativa entre el compromiso de la organización y la gestión del conocimiento. Asimismo, existe una correlación entre la variable que predice los valores organizacionales y la variable de gestión del conocimiento, mientras que no existe una relación significativa entre la variable de compromiso organizacional y la de gestión de conocimiento.
}

Palabras clave: valores organizacionales; compromiso organizacional; gestión del conocimiento 


\section{Statement of the problem}

Despite the fact that the power of knowledge is considered indisputable, today legal and natural persons use knowledge to various ends. The modern day's problem is not accessing, but the management of knowledge. If an organization fails to recognize or utilize its sources of knowledge, it would have a meagre chance of survival (Saliss \& Jones).

Individual and collective values along with human and moral values have been the focus of attentions of psychology and management researchers. This has been developed under such terms as moral values, social values, economic values and political values (Aldrich, Girmsrud, Thacher\&Kotchen, 2007; Bilsky\&Jehn, 2002; Seevers, 2000). In the same fashion, organizational commitment is considered to be a psychological bond between the staff to the extent that it may reduce the possibility that they leave the organization deliberately (Allen, N. J., \& Meyer, 1996). Organizational commitment is, in fact, one of the predictors of behaviors in organizations that show effects on some work issues like reduction of absence, futile work behaviors and quitting (Riketta, 2002). The knowledge management can improve an array of organization functioning through making the organization act wisely. However, this is not sufficient, since the knowledge managementcannot be carried out unlessthe organization has staff who are devoted to the process of knowledge management and its execution. Thus, the present research seeks the following goals:

1. Determining the relationship between organizational values and knowledge management among the staff of Kermanshah's Tax Department

2. Determining the relationship between organizational commitment and knowledge management of the staff of Kermanshah's Tax Department

3. Determining the share of organizational values variable and organizational commitment in predicting the knowledge management of Kermanshah's Tax Department staff.

\section{Methodology}

The present research is practical from the viewpoint of its aim, and is survey-descriptive regarding its data collection method also, correlational from the view of its relationship. The Statistical population of this study consists of 396 staff members of Kermanshah's Tax Organization, 195 individuals of whom were chosen according to stratified sampling. Regarding data collection, the Golparvar et al (2010) questionnaire was used for organizational values, Nonaka\&Takuchi (1998) questionnaire for 
knowledge management and Allen\&Meyer (1996)questionnaire for organizational commitment. The reliability of these questionnaires were calculated to $0.698,0.775,0.776$ respectively. In order to test the hypotheses the Pearson Correlation Coefficient and General linear model were used.

\section{Findings}

- There is a meaningful correspondence between organizational values and knowledge management.

The Pearson Correlation Coefficient between organizational values and knowledge management is 0.231 and its level of significance is 0.001 . Hence, the level of significance is lower than the testing error and the hypothesis is accepted.

- There is a meaningful relationship between organizational commitment and knowledge management.

The Pearson Correlation Coefficient between organizational commitment and knowledge management is -0.082 and its level of significance is 0.255 . Comparing the level of significance to the testing error, 0.05 appears which means that the level of significance is higher than the testing error and the hypothesis is rejected.

- There is a meaningful correspondence between variables of organizational values and those of knowledge management.

In Regression Model table, where knowledge management variable is considered to be an independent variable and some variables like human values, human and common relationship values, customer -related values, social values outside of the organization, supportive economic values are deemedas prediction variables, the latter variables got $-0.21,0.252,0.296,-0.115,0.638$ respectively. The results showed that all of the variable's level were greater than the testing error 0.05 . Hence, none of the prediction variables had a meaningful relationship with independent variable.

- There is a meaningful relationship between variables of organizational commitment and those of knowledge management

In Regression Model table, where knowledge management variable is considered to be an independent variable and some variables like emotional, consistent and norm factors were the prediction variables, the latter variables got $-0.306,-0.178,0.014$. Likewise, it was proved that the significance level of emotional prediction variable was 0.003 , which is lower than the testing error. Hence, it could be inferred that emotional prediction variable is in a meaningful correlation with knowledge management but consistent and norm factors do not have any relationship with knowledge management variable.

- An investigation of exploratory factor analysis of the study. The exploratory factor analysis of knowledge management variable 
The results of the experiment proved that the coefficient of knowledge management in direct relation to organizational values is 0.231 and in indirect relationship and under the influence of organizational commitment equals to 0.124 , both of which possessed a meaningful correlation. In the same fashion, the coefficient of knowledge management in direct relation to organizational commitment is -0.082 and in indirect relationship and under the influence of organizational value equals to -0.015 , both of which lack a meaningful correspondence.

- The exploratory factor analysis of knowledge management variable and organizational values

The results show that, among all of the variables of organizational values, knowledge management has the strongest relationship with supportive economic values which is 0.638 and ha the weakest correspondence with humanistic and moral values whichis -0.021 .

- The exploratory factor analysis of knowledge management variable and organizational commitment

Among all of the variables of organizational commitment knowledge management has the strongest relationship with emotional variable which is -0.306 and the weakest with norm variable which is 0.014 .

\section{Discussion and conclusion}

Combined with personal values, organizational values determine a general sketch of cultural and value tendencies within an organization. Transformational leaders ideologically inspire the staff and make them pay attention to their limitations. Eventually, this attention enhances the effectiveness of the individuals in pursuing collective goals. Other types of leadership that are interconnected with Transformational leadership include ethical and charismatic leaderships. The result of the experiment demonstrated that there is a meaningful correspondence between organizational values and knowledge management, which accords with the researches carried out by Belsky and Jen (2002) and Schwabbruck, Lahm and Cha (2007).

The results of the study performed on organizational commitment, knowledge management and level of significance proves that there is no meaningful relationship between organizational commitment and knowledge management, which contradicts the results of the researches done by Bordbar (2014) and Ghornjikandlri (2013).

Recently, knowledge management has become a vital issue. Scientific and commercial societies both believe that organizations would be able to keep their long term ascendency using the power of knowledge and the experts have found that unlike other types of management, knowledge management is not transient but long- lasting. Naturally, only the organizations that are able to maintain their competitive advantage 
can survive. This cannot be achieved, the experts believe, unless knowledge management is utilized. The first step towards management based on values in an organization, is the sheer acceptance of its philosophy from the side of the public. The staff must believe that a management based on values benefits the organization. I fact, the importanceof the values lies in the fact that they help the staff to have their proper position in pursuing the aims of their organization. In the domain of goals, the most secure path is not the most direct one but regarding the issue of values, the paths are always direct and the leaders and managers must insist on following this direct line.

Human resource is considered one of the crucial and strategic factors in any organization and one of its most valuable possessions. Human resources is the basis for achieving competitive advantage and organizational capability. The staff are among an organization's most valuable possessions, but the approach of outstanding organizations towards employing and utilizing them differs from other organizations.

In creating ideal companies, leniency is meaningless, since the levels of expectation of these companies is higher compared to that of others (both from the viewpoint of staff performance and their compatibility with the company's worldview). A particular worldview or philosophy cannot be forced into an individual's life, but each individual must have the potentiality for attracting a certain set of ideological values prior to their acceptance. The managers' duty is to find those individuals who are already prepared to accept their worldview.

The rule of thumb in famous organizations is (first the individual, then the goal). These companies realize that the reason behind each organization's growth is not the market, technology, competition or the type of products but the ability to employ and maintain the suitable human work force. Hence it could be generally stated that human resources are not the most valuable possessions of an organization, but deserving and worthwhile human resources are the most precious property of a company. Famous companies are patient and meticulous in their recruitment and emphasize appropriate selection and choose individuals on basis of their personality traits and compatibility with the company's ideological principles.

The synchronization of the current activities and organizational decision-making with the ideological system and the code of conduct requires the realization of one fundamental principle: organizational values are closely intertwined with the organization's survival. Therefore, the mere act of designing values manifesto does not guarantee the organization's survival, but the deployment of values and their internalization within various processes of the organization serve as a warrant for the organization's life and survival.

To this end, the leaders and Chief administrative officers play crucial roles inthe designation and deployment of values, to the extent that they must act as the role models of progression and defendants of ideological system of the organization. Thus, in the selection and employment of the managers, the level of their behavioral and verbal 
concordance with the values and ethical principles of the organization seems to be an inevitable necessity, especially in the issue if chief managers and officers.

Taking into account the advantages of compiling and deploying the organizational values and professional ethics, a huge number of organizations and enterprises are far from their ideal spirit and functioning despite their attempts to create ideological principles, ethical codes, guidelines and professional ethics.

Organizational values can be deployed through the following ways:

- The compatibility of individual and organizational values.

- A precise definition of the behavior that is concordant with organizational values

- The beneficial utilization of organizational values and the related behaviors in the functioning management system of organization like 360 degree feedback.

- The utilization of values in the process of employment.

- Emphasizing the organizational values in the meetings and current interactions of the organization.

- Consideration of organizational values in the strategic plan through setting operational targets.

- Organizational focus on designated values and the values within the process of change management.

The positive upshots and advantages of deploying the values in organizations has created a fertile ground for a new concept of management within the domain of management which is based on the values.

\section{References}

Aldrich, G.A., Girmsrud, K.M., Thacher, J.A., \& Kotchen, M.J. (2007). Relating environmental attitudes and contingent value: how robust are methods for identifying preference heterogeneity. Environment Resource Economy, 37, 757 - 775.

Allen, N. J., \& Meyer, J. P. (1996). Affective, continuance, and normative commitment to the organization: An examination of construct validity. Journal of Vocational Behavior, 49, 252-276.

Bilsky, W., \&Jehn, K.A. (2002). Organizational culture and individual values: evidence for a common structure. In Myitek, M. (Ed.), Die person imbiologischen und sozialon context (pp. 211- 228). Gottingen: Hogrefe.

Bordbar, H. (2014). The relationship between knowledge management and organizational commitment and professional dedication of staff (Case study: oil company in south of Iran). M. A. Thesis, Tehran University.

Gharanjik, E. \& Irie, J. (2012). Examining the relationship between organizational commitment and willingness of employees to organizational knowledge sharing among staff and faculty members of Azad University of Golestan province. First Annual Conference on Modern Management. Tehran, Iran. 
Golparvar et al. (2010). Moral values and ethical leadership role in reducing job stress. Ethics in Science and Technology. Winter and Fall 2010, 5 (III-IV), 67-76.

Nonaka, I \& Takeuchi, H. (1998). The Knowledge Creating Company: How Japanese Companise Creat the Dynamics of Innovation. Newyork: Oxford University Press.

Riketta, M. (2002). Attitudinal organizational commitment and job performance: A Meta - analysis. Journal of Organizational Behavior, 23, 257-266.

Sallis, E \& Jones, G. (2002). Knowledge Management in Education. Great Britain: Kogan Press.

Seevers, B.S. (2000). Identifying and clarifying organizational values. Journal of Agricultural Education, 41 (2), $70-79$

Schaubroeck, J. Lam, S.S.K. \& Cha, S. E. (2007). Embracing Transformational leadership: team values and the impact of leader behaviour on team performance. Journal of Applied Psychology, 92 (4), 1020-1030.

Mehdi Sadeghi

Islamic Azad University Branch of Kermanshah: Kermanshah, Iran 2000-10-01 to present | dr (education management)

Email:mehdisadeqi@yahoo.com

Orcid: 0000-0002-2763-0817

Sara Yazdanfar

Communication society of science (M.A),

Expert in International cooperation affairs. Kermanshah - Razi University, Iran

Email: yazdanfar.s@gmail.com

\section{Correspondência}

Mehdi Sadeghi

Islamic Azad University Branch of Kermanshah: Kermanshah, Iran 2000-10-01 to present | dr (education management)

Data de submissão: Dezembro 2016

Data de avaliação: Janeiro 2017

Data de publicação: Março de 2018 